\title{
Analysis of Groundwater Flow Modelling: The Case of Hormat-golina Sub-basin, Golina Basin, Ethiopia
}

\author{
Mengesha Tesfaw ${ }^{1,}$, , Tewodros Assefa Nigussie $^{2}$, Sirak Tekleab ${ }^{2}$ \\ ${ }^{1}$ Department of Water Resource and Irrigation Engineering, Woldia University, Woldia, Ethiopia \\ ${ }^{2}$ Department of Water Resource and Irrigation Engineering, Hawassa University, Institute of Technology, Hawassa, Ethiopia \\ Email address: \\ mengesha816@gmail.com (M. Tesfaw), hiyawtewodros@gmail.com (T. A. Nigussie), siraktekleab@gmail.com (S. Tekleab) \\ ${ }^{*}$ Corresponding author
}

\section{To cite this article:}

Mengesha Tesfaw, Tewodros Assefa Nigussie, Sirak Tekleab. Analysis of Groundwater Flow Modelling: The Case of Hormat-golina Subbasin, Golina Basin, Ethiopia. Hydrology. Vol. 9, No. 2, 2021, pp. 48-55. doi: 10.11648/j.hyd.20210902.13

Received: March 9, 2021; Accepted: May 11, 2021; Published: June 4, 2021

\begin{abstract}
Analysis of the Groundwater flow can help to understand future water potential. This study has explored the predicted groundwater flow dynamics with climate change and anthropogenic stress in Hormat-Golina Sub-basin. Groundwater flow modeling in this Sub-basin has provided information about groundwater quantity as well as the quality aspect for decision-makers about groundwater accessibility. The initial head measured values before and after irrigation season has varied to a maximum of $0.8 \mathrm{~m}$. The groundwater head level before and after irrigation season was varying from $9.3 \mathrm{~m}$ to $8.26 \mathrm{~m}$ in the Southern boundary. The groundwater head was obtained from $41.5 \mathrm{~m}$ to $38.83 \mathrm{~m}$ in the northwestern of the Subbasin. The maximum drawdown depth had found to $0.27 \mathrm{~m}$ and $2.6 \mathrm{~m}$ before and after irrigated season around the pumped wells. The increased pumping rate with decreased recharge rate was replying to the groundwater head at the end of 2021 decreased by $2.81 \mathrm{~m}$ in the northwestern boundary of the Sub-basin as compared as using constant pumping rate with recharge rate. While decreased pumping with increased recharge rate was replying to the groundwater head at the end of 2021 has increased by $2.23 \mathrm{~m}$ in the northwestern boundary of the Sub-basin as compared as using constant pumping rate. The impacts of climate change and human pressure on groundwater begot as the threats in those supply wells. Decreased pumping with increased recharge rate was accomplishing to restore and protect the groundwater resources, which is the best option for groundwater restoration and monitoring.
\end{abstract}

Keywords: Groundwater Head, Irrigation, Climate Change, Hormat-Golina, Ethiopia

\section{Introduction}

Groundwater in many parts of the world is at risk because of increasing demands, mismanagement, and contamination with anthropogenic activities. The availability of groundwater can be determined by the nature of the geology including the porosity, hydraulic conductivity, the characteristics of the rocks, the type of the aquifer, and generally the hydro-geological nature of the aquifer $[8,10]$.

Climate change can influence the groundwater system, both direct recharges due to precipitation and indirectly through changes in groundwater uses $[2,4,5]$. Climate change can alter the global hydrological cycle in terms of distribution and availability of regional water sources. Human pressure deals with overconsumption of groundwater by pumping can distort the natural recharge-discharge equilibrium [7].

Groundwater modeling is a tool used for water resources planning and management, groundwater protection, and giving recommended remedial action by considering the output of the model $[3,6]$.

In Ethiopia, there are many irrigation projects, among which Raya Kobo Irrigation Project is one that mainly depends on the groundwater source. All groundwater studies had not been explored in the previous through the predicted groundwater flow dynamics concerning climate change and anthropogenic stress. But this study has developed on the groundwater fluctuation to human pressure and climate change.

Hence, the present study has initiated to quantify the groundwater head and its respected drawdown level in 
irrigated and non-irrigated season. Due to the lack of continuously recorded data of this groundwater head and its prediction was developed by considering human interference and natural conditions as a scenario-based analysis.

\section{Material and Methods}

\subsection{Description of the Study Area}

This study has carried out in the Hormat-Golina Sub-basin of the Kobo Girana Irrigation Project. This Sub-basin is found in Kobo District under the Golina-Basin. HormatGolina Sub-basin has an attitude ranging from $1400 \mathrm{~m}$ to $3100 \mathrm{~m}$ above sea level. The study area has situated between $39^{\circ} 14^{\prime} 0^{\prime \prime}$ to $39^{\circ} 45^{\prime} 0^{\prime \prime} \mathrm{E}$ Longitudinal and $12^{\circ} 2^{\prime} 0^{\prime \prime}$ to $12^{\circ} 20^{\prime} 0^{\prime \prime}$ $\mathrm{N}$ Latitude geographical coordinate system (Figure 1).

The groundwater divide line is the upper boundary of the Hormat-Golina Sub-basin (MCE, 2009). The topography is bound Zobel Mountain in the Eastern direction. The Mountain is separate from the lowlands of the Afar region, which has over $3100 \mathrm{~m}$ high above sea level.

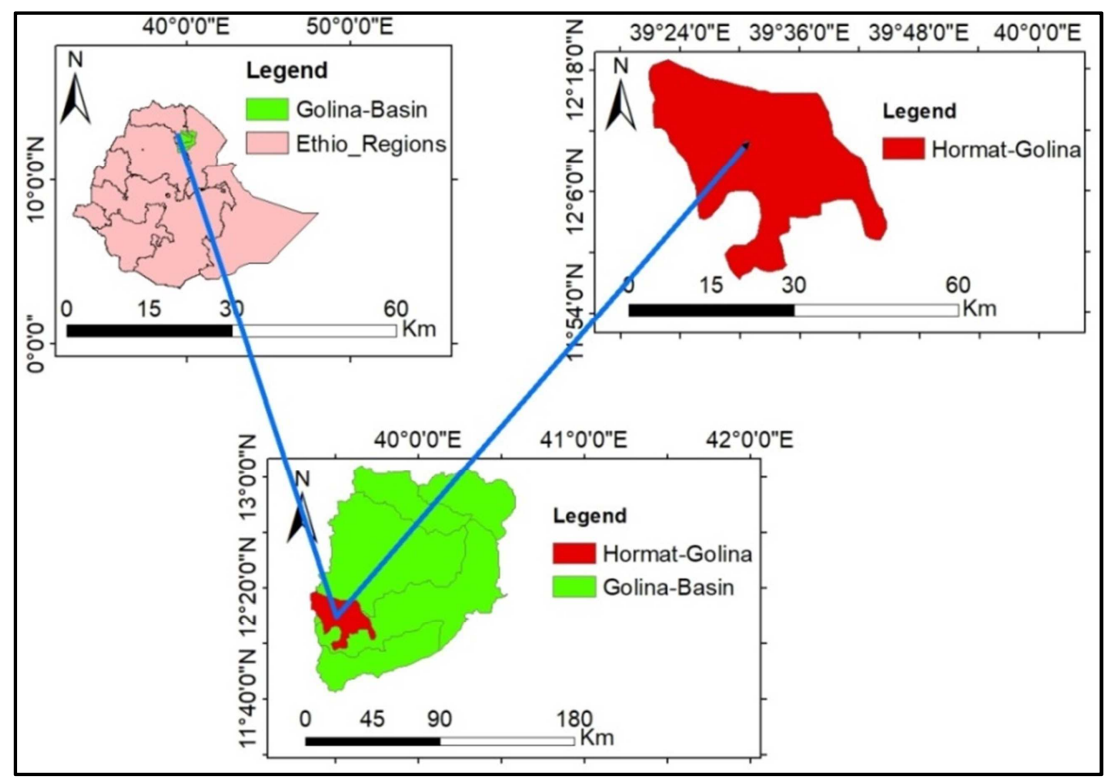

Figure 1. Location map of the study area.

Hormat-Golina Sub-basin has been categorizing as a semiarid climate condition. Kobo-Girana valley plain and has ranged from $12^{\circ} \mathrm{C}$ in December to $35^{\circ} \mathrm{C}$ in April. The rainfall distribution is not evenly, since orographic effects modify the distribution of rainfall over the area. The principal feature of rainfall distribution in the Sub-basin has characterized by seasonal, poor distribution, and erratic.

Based on field observation and Satellite image (USGS, Land sat image, 2019), the Sub-basin had Agricultural land, Forest Land, Urban area, water body, and Bare land types of land-use land cover units. Among those land-use units' Agricultural land use units had the dominant land-use land cover units while Water body land-use land unit had small area coverage.

The study area has located near the highlands of Zobel Mountain from the Eastern direction and highlands on the NorthWestern side. From the previous Geological study was carried out by Metaferia Consulting Engineers (MCE, 2009) and Geo-Engineering Service (GES, 2003), the aquifer in the kobo-Girana valley had mainly unconsolidated sediment.

The Northwestern highlands have originated from Basaltic rocks. The Eastern Ridge (Zobel Mountain) originated from the Rhyolite, while the valley floor originates from alluvial deposits.

\subsection{Data Collection and Analysis}

Investigating this groundwater head and flow direction in the irrigated and non-irrigated season was depending on the combination of primary and secondary data. The Primary data has been taken from the measured groundwater heads in different pumping and monitoring wells. The secondary data has been taken from recorded meteorological data, geological characteristics and litho-logical depth from Metaferia consulting Engineers and Geo Engineering Services reports.

\subsubsection{Climate Data}

The climate data has been taken from the Meteorological station to understand in detail climatic conditions in response to the groundwater contribution. In the study area, the climate data and its observation parameters have evaluated the groundwater head with a response to the surface nature of the topography. Data of the following climate parameters were collected and analyzed: precipitation, evapotranspiration, temperature, and recharge.

Understanding the rainfall characteristics on the surface of the study area can reflect its contribution to groundwater recharge. According to Waterloo Hydrologic (2015), where the water table is above the ground surface, the evapotranspiration loss from the water table occurred at the maximum rate. While the elevation of the water table is below layer 1 , the evapotranspiration from the water table is negligible.

The Recharge rate is to simulate the amount of water that contributed to the groundwater level. The groundwater 
recharge has had computed by Roorkee's empirical estimation of a recommended regions based on water level fluctuation, and rainfall depth became $39.055 \mathrm{~mm} / \mathrm{yr}$.

Due to the lack of relevant information for computing recharge contribution from the ground surface, Roorkee's empirical estimation had selected.

\subsubsection{Hydrogeology/Geological Data}

The aquifers in the study area had mainly alluvial deposits, fractured and weathered basalts. The Sub-surface groundwater flows characterization in the study area has been designed based on the results from both previous studies and pumping test data. The sediment thickness has varied from 18 to $212 \mathrm{~m}$ an average depth of $129 \mathrm{~m}$ [9].

Table 1. Geological characteristics of the sub-basins.

\begin{tabular}{lll}
\hline \multirow{2}{*}{ Aquifer characteristics } & Hormat-Golina & \\
\cline { 2 - 3 } & Range & Average \\
\hline Sediment thickness (m) & $18-212$ & 129 \\
Aquifer thickness (m) & $20-150$ & 90 \\
Water Table depth (m) & $9-41.5$ & 25 \\
Average Saturated thickness (m) & & 104 \\
\hline
\end{tabular}

\subsubsection{Existing Wells Characteristics}

The Sub-basin has 34 functional pumping wells and eight observation wells (KGVDPO). For this analysis, irrigation boreholes and Kobo town water supply wells that tap on the alluvial aquifer had used. Not all boreholes are using for irrigation at present. Currently, no continuous recorded groundwater data was available concerning how the groundwater has been utilizing during the irrigation period within the existing wells. The pumping time during irrigation seasons has been varying from 8 hours to 16 hours. The pumping and observation wells have densely populated in the Western boundary of the Hormat-Golina Sub-basin. The lithological characteristic of each well had initially assessed by Metaferia Consulting Engineers (MCE, 2009). The majority of water level measurements have been taking from pumping wells without monitoring wells.

\subsubsection{Estimation of Aquifer Parameters}

The groundwater flow model has required many different types of data to simulate the hydro-geological processes influencing the groundwater flow. The hydro-geological characteristics of the given aquifer have the following flow property parameter groups; Hydraulic Conductivity, Storage, and Initial heads. The hydraulic conductivity values had computed from the Aquifer test model based on the pumping test data. The pumping test data has been using to determine the aquifer hydraulic parameters such as; hydraulic conductivity and specific yield value can use as the model input parameters.

Table 2. The values of aquifer flow properties.

\begin{tabular}{ll}
\hline Parameters & Value \\
\hline Hydraulic conductivity $(\mathrm{m} / \mathrm{s})$ & 0.0003 (Unconsolidated material) \\
Specific yield & 0.2 \\
Initial heads $(\mathrm{m})$ & Measured depth \\
\hline
\end{tabular}

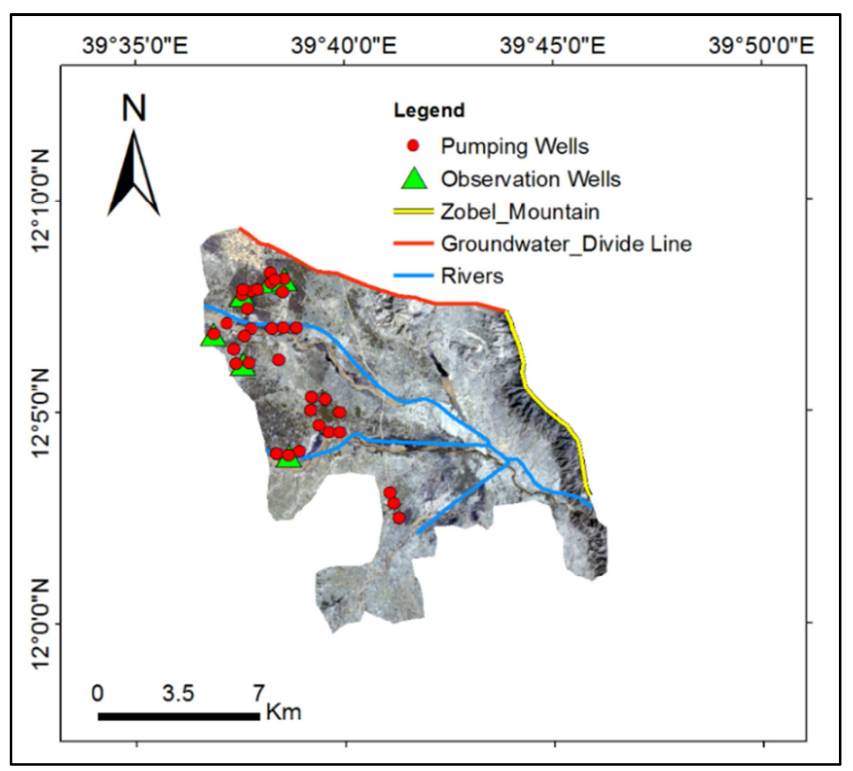

Figure 2. The location of pumping and observation wells.

\subsubsection{Boundary Conditions}

Boundary conditions are the components in conceptualizing the groundwater flow system. The conceptual model has required an appropriate set of boundary conditions to represent the system's relationship with the surrounding environment. The pumping wells and recharge boundary conditions had modeled for simulating this groundwater flow. However, due to the lack of recorded information and flow measurement of head and river boundary conditions had not been modeled.

\subsubsection{Model Assumptions}

Model simulation has been using spatial and temporal data from various sources. Some assumptions had also made due to the lack of information:

1) Due to the lack of detailed distribution of groundwater recharge, the previous groundwater recharge in the Subbasins had taken from the literature $(53.5 \mathrm{~mm} / \mathrm{yr})$.

2) The specific yield has assumed to be range from 0.13 to 0.27 on average.

3) Decreased pumping rates by half in the sub-basins have met the community's minimum water requirement.

4) During the dry season, all pumping wells should be functional.

\subsection{Analysis of the Groundwater Flow Data}

\subsubsection{Groundwater Head and Flow Direction During in Stress Periods}

In this study, groundwater head was determined in two stress periods (before irrigation and after irrigation periods). The groundwater head under the non-irrigation period has stated that there was no available pumping rate for irrigation activity. Unlike the irrigated wells, Kobo town water supply wells hadn't been closed in the non-irrigated season. The pumping boundary condition for the water supply well had been taken into account. In the second case, the study had conducted through the measured groundwater head after 90 
days' irrigation period.

The pumping time had varied with different crop growth stages. From those fifteen irrigation wells and two Kobo town water supply wells had a total of $9.333 * 103 \mathrm{~m} 3 /$ day of groundwater was abstracting within Ninety days supply period.

\subsubsection{Simulation of Groundwater Dynamics Due to Stresses}

Due to the lack of continuously recorded groundwater data in the Sub-basin, it was difficult to predict future groundwater head and its respected drawdown level. Based on the measured groundwater data, the groundwater dynamics were predicting within different stress conditions. The study area has located in Semi-arid conditions; climate change had a role in controlling the groundwater dynamics. The calibrated model had run for different scenarios-based analyses with climate change and human-induced impacts concerning simulation times.

Table 3. Simulation of modeling for different scenarios.

\begin{tabular}{|c|c|}
\hline Simulation 1: Human pressure & Description \\
\hline Scenario 1 & Measured constant recharge rate of $39.055 \mathrm{~mm} / \mathrm{yr}$ and pumping rate had $23.2838^{*} 10^{3} \mathrm{~m}^{3} / \mathrm{d}$ using 17 wells \\
\hline Scenario 2 & The second pumping rate had $\left(12.9048 * 10^{3} \mathrm{~m}^{3} / \mathrm{d}\right)$ due to stresses using 10 boreholes decreased by $55.4 \%$ of from scenario one \\
\hline Scenario 3 & $\begin{array}{l}\text { The third pumping rate has increased from the pumping rate by } 53.3 \%\left(43.6849^{*} 10^{3} \mathrm{~m}^{3} / \mathrm{d}\right) \text { of the current rate in order } \\
\text { to meet the daily water consumption from } 34 \text { boreholes }\end{array}$ \\
\hline \multicolumn{2}{|l|}{ Simulation 2: climate change } \\
\hline Scenario 4 & $\begin{array}{l}\text { The pumping rate has increased its rate }\left(43.6849 * 10^{3} \mathrm{~m}^{3} / \mathrm{d}\right) \text { using } 34 \text { wells influence by pressure of resources with a } \\
\text { decreased recharge rate by } 27 \%(28.51 \mathrm{~mm} / \mathrm{yr})\end{array}$ \\
\hline Scenario 5 & The pumping rate has decreased its rate $\left(12.9048 * 10^{3} \mathrm{~m}^{3} / \mathrm{d}\right)$ using 10 wells with increased recharge rate by $27 \%(53.5 \mathrm{~mm} / \mathrm{yr})$ \\
\hline
\end{tabular}

Under the transient state model, two stress conditions (pumping and recharge) had selected with different scenarios. In these two years' groundwater level prediction, the boundary conditions and land-use land-cover conditions had been constant. The irrigation time within those two years had 330 days, and 731 days for Kobo town domestic consumption produced used as the time step. Pumping time was varying from a maximum of 16 hours to 8 hours.

\subsection{Groundwater Model Setup}

During model setup conceptual model has been established throughout considering model inputs including; flow property within an existing boundary condition to develop the numerical model. The accuracy of the model has been judged by the root mean square value of the square root of the sum of the square of the differences between calculated and observed heads and concentrations, divided by the number of observation wells [1].

Model calibration had stopped at the end of the simulation when matches between the observed and calculated hydraulic heads and transports model have achieved. After each run, differences between simulated and measured heads had calculated every difference should be minimal. The model calibrations had indicated a reasonably good match between the observed and calculated hydraulic head and transport concentrations. The model performance had achieved through different scenarios representing insights about the future changes in groundwater due to pumping and recharges rates.

\subsection{Groundwater Governing Equations}

A general form of governing groundwater equation in the three-dimensional non-equilibrium movement of groundwater with constant density through porous, threedimensional, and heterogeneous flow of groundwater has been described by the partial differential equation (Freeze and Cherry, 1979) see on the following equation 1.

$$
\frac{\partial}{\partial x}\left(K x \frac{\partial h}{\partial x}\right)+\frac{\partial}{\partial y}\left(K y \frac{\partial h}{\partial y}\right)+\frac{\partial}{\partial z}\left(K z \frac{\partial h}{\partial z}\right) \pm w=S s \frac{\partial h}{\partial t}(1)
$$

Where $\mathrm{Kx}, \mathrm{Ky}$ and $\mathrm{Kz}$ are the hydraulic conductivity along the $\mathrm{x}, \mathrm{y}$ and $\mathrm{z}$ directions $\left(\mathrm{LT} \mathrm{T}^{-1}\right.$ )

$\mathrm{h}$ is potentiometric head (L), $\mathrm{W}$ is the volumetric flux per unit volume and represents the sources and/or sinks of water per unit time $\left(T^{-1}\right)$, Ss is specific storage of the porous material $\left(L^{-1}\right.$ and $\mathrm{T}$ is the time $(\mathrm{T})$.

\subsection{Model Discretization}

The conceptual model has used the central finite difference method, which involves fitting the conceptual model to finite-difference grids. These allow confirming the grid to each well and boundary conditions. In Hormat-Golina Subbasin, the numerical model has mapped with 40 rows and 40 columns with the corresponding cell height of 636.324 and $442.588 \mathrm{~m}$ along the $\mathrm{X}$ and $\mathrm{Y}$ direction. Deformed grid type was selected for (the tops and bottoms of the model layers follow the horizons elevations).

\section{Result and Discussions}

\subsection{Groundwater Head in Irrigated and Non-irrigated Season}

The groundwater head in Hormat-Golina Sub-basin had analyzed by different stress periods (before and after irrigation season). When the irrigation period was starting, the drawdown level has changed with time since the static water level has already varied. Hydraulic conductivity was a more sensitive parameter for the groundwater flow model.

After calibration, the model had completed for different irrigation season, the standard error of the calculated and observed head was $0.46 \mathrm{~m}$ and $0.49 \mathrm{~m}$. 
Table 4. Groundwater flow model performance characteristics.

\begin{tabular}{lll}
\hline Model status & before irrigation & After irrigation \\
\hline Standard error of the estimate $(\mathrm{m})$ & 0.46 & 0.49 \\
Root mean square $(\mathrm{m})$ & 1.83 & 2.01 \\
Normalized root mean square (\%) & 4.95 & 5.37 \\
Correlation coefficient & 0.98 & 0.98 \\
\hline
\end{tabular}
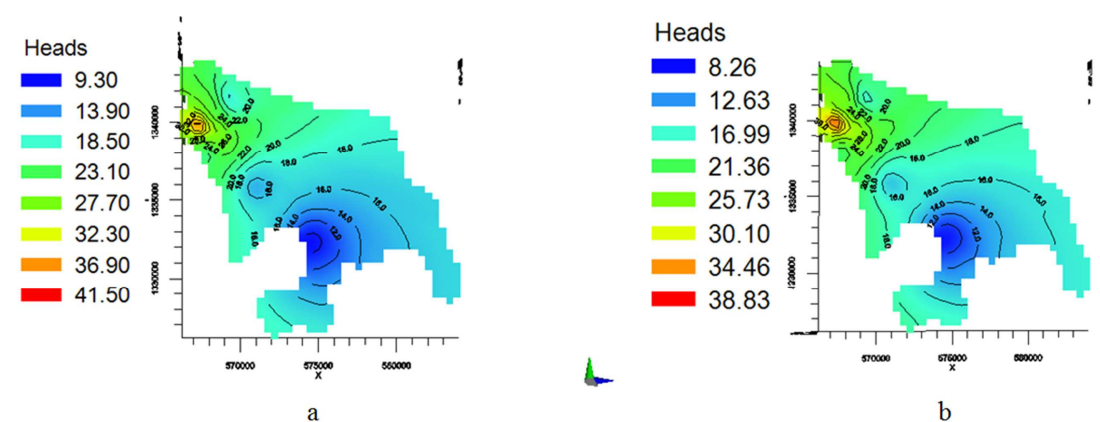

Figure 3. The model result for before and after irrigation season.

The above figure (Figure 3) had shown that the groundwater head before irrigation season (a) and after irrigation season (b). The model result has already from the above figure (Figure 3 a), the groundwater head level before irrigation season was varying from $9.3 \mathrm{~m}$ in the Southern boundary to $41.5 \mathrm{~m}$ in the northwestern side of the Sub-basin.

The model result has shown from the above figure (Figure 3 b) the groundwater head level in irrigation season was varying
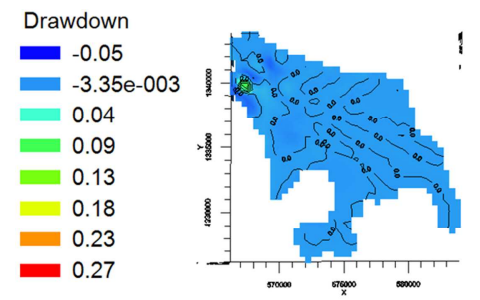

a from $8.26 \mathrm{~m}$ in the Southern boundary to $38.83 \mathrm{~m}$ in the Northwestern area of the Sub-basin. Compared to both seasons (before and after irrigation), groundwater declination can't be fully compensated by groundwater recharge in areas where the Western boundary which has dense irrigation boreholes. Furthermore, the groundwater table for irrigation season was emphasizing on more water table variation had greater on the Northwestern area than the Eastern area of the Sub-basin.

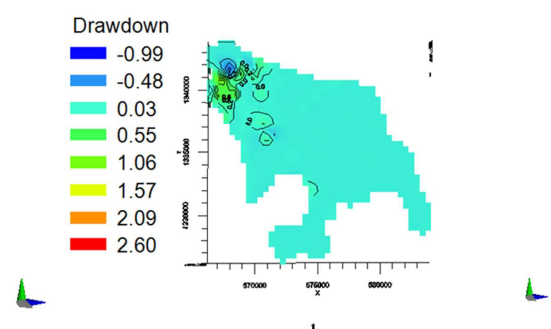

Figure 4. The drawdown level in before and after irrigation season.

From the above figure (Figure 4 a), the drawdown level has shown that the maximum depth of $0.27 \mathrm{~m}$ found in the non-irrigated season around the pumped wells. In the above figure (Figure $4 \mathrm{~b}$ ), the drawdown level has shown that the maximum depth of $2.6 \mathrm{~m}$ found in the irrigated season around the pumped wells.

\subsection{Simulation of Groundwater Dynamics Due to Stresses}

\subsubsection{Groundwater Head}

The scenario-based groundwater flow prediction result had applied with different stress conditions (pumping and recharge rates). After calibration, the model had completed in different stress periods. The standard error of the calculated and observed head for simulation 1 (scenario 1, scenario 2, and scenario 3 ) has found $0.56 \mathrm{~m}, 0.72 \mathrm{~m}$, and $0.42 \mathrm{~m}$.

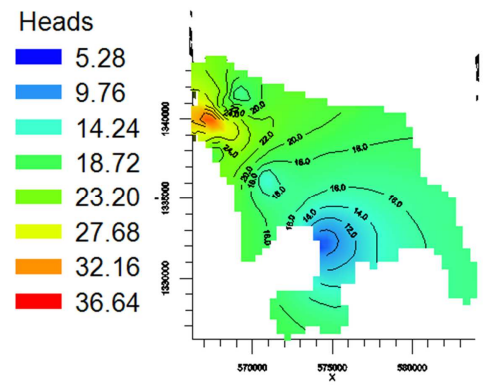

Figure 5. The predicted groundwater head with constant rate.

Table 5. Groundwater flow model performance result for scenario analysis.

\begin{tabular}{llll}
\hline Model status & Scenario 1 & Scenario 2 & Scenario 3 \\
\hline Standard error of the estimate (m) & 0.56 & 0.72 & 0.42 \\
Root mean square (m) & 2.28 & 2.18 & 2.47 \\
Normalized root mean square (\%) & 6.11 & 5.84 & 0.55 \\
Correlation coefficient & 0.98 & 0.99 & 0.94 \\
\hline
\end{tabular}


In the above figure (Figure 5), the predicted groundwater head values had shown that constant pumping and recharge rate. In the first simulation scenario 1 , the predicting estimation of human pressure (pumping rate) and climate change (recharge
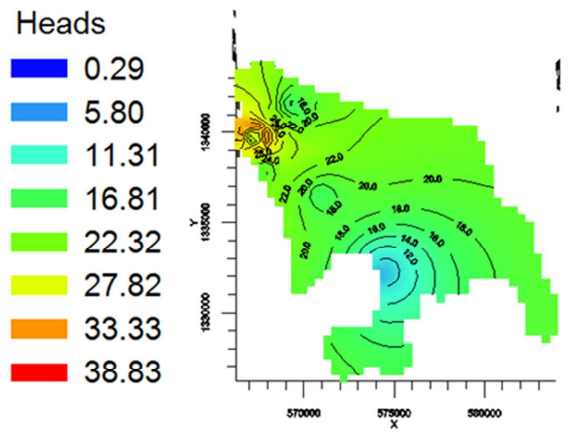

rate) has been constant, and its level was varying from $5.28 \mathrm{~m}$ in the Southern boundary to $36.64 \mathrm{~m}$ in the northwestern boundary. For Simulation 1scenario 2 and scenario 3, the following groundwater head result was showing.
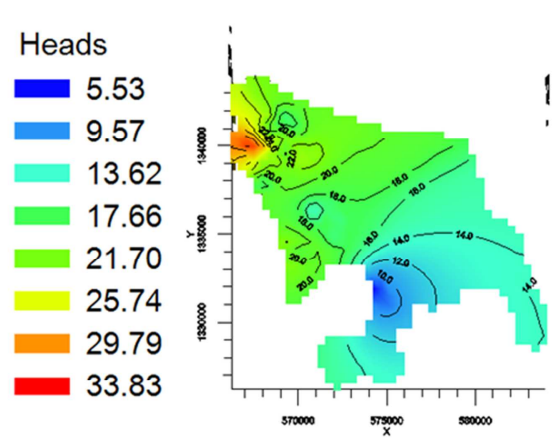

$\mathrm{b}$

Figure 6. The predicted groundwater head result due to change of pumping well.

In the above figure (Figure 6 a), in the first Simulation scenario 2 , the groundwater head had highly varied in the response of decreased pumping rate. The groundwater head level due to the decreased pumping wells by half with constant recharge had varied from $5.8 \mathrm{~m}$ in the Southern boundary to $38.83 \mathrm{~m}$ in the northwestern direction of the Sub-basin. The predicted groundwater head at the end of 2021 has increased by $0.52 \mathrm{~m}$ in the floor of the Sub-basin and increased by $2.19 \mathrm{~m}$ in the northwestern boundary of the Sub-basin as compared to the previous groundwater head determination scenario (Scenario 1).

The model result from the above figure (Figure $6 \mathrm{~b}$ ) in the first Simulation (scenario 3) had shown that the groundwater head level due to the increased pumping wells by double with constant recharge rate. The groundwater head was varying from $5.53 \mathrm{~m}$ in the Southern boundary to $33.83 \mathrm{~m}$ in the Northwestern direction of the Sub-basin. The increased pumping rate had replied to the groundwater head at the end
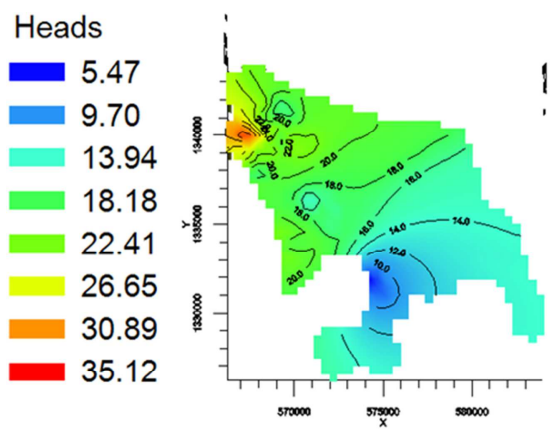

a of the predicted period (2021) was increase by $0.27 \mathrm{~m}$ on the valley floor of the Sub-basin. The groundwater head was decreasing by $2.81 \mathrm{~m}$ in the northwestern of the Sub-basin as compared to the previous groundwater head determination scenario (Scenario 1).

In the second simulation scenario, 4 and 5 had shown that the groundwater characteristics concerning climate change. After calibration, the model had completed in different stress periods the following model performance results were measuring.

Table 6. Groundwater model performance result for scenario analysis

\begin{tabular}{lll}
\hline Model status & Scenario 4 & Scenario 5 \\
\hline Standard error of the estimate $(\mathrm{m})$ & 0.42 & 0.72 \\
Root mean square $(\mathrm{m})$ & 2.46 & 2.19 \\
Normalized root mean square (\%) & 6.53 & 5.84 \\
Correlation coefficient & 0.94 & 0.99 \\
\hline
\end{tabular}

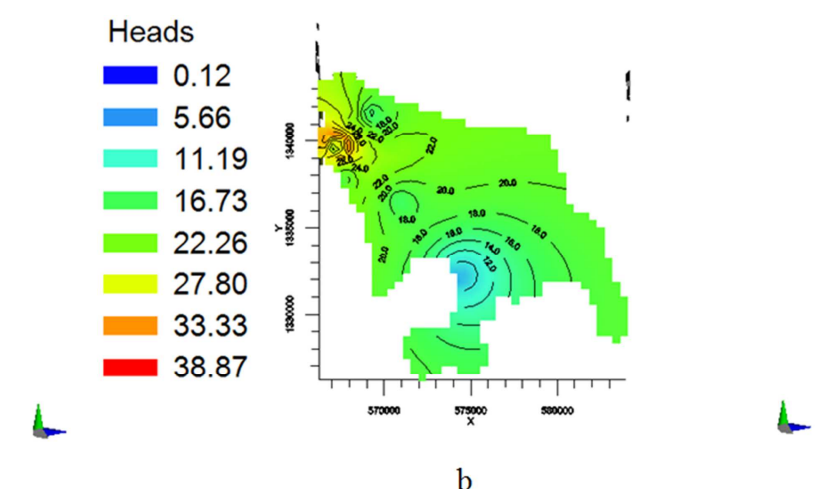

b

Figure 7. The predicted groundwater head with variation of recharge rate.

In the above figure (Figure 7 a) in the second simulation scenario 4 , the groundwater head due to climate change with human pressure was varied from $5.47 \mathrm{~m}$ in the Southern boundary to $35.12 \mathrm{~m}$ in the northwestern of the Sub-basin. The increased pumping rate was replying to the groundwater head at the end of the predicted period (2021) has increased by $0.19 \mathrm{~m}$ in the floor of the Sub-basin due to the drain effect of the flow and decreased by $1.52 \mathrm{~m}$ in the northwestern boundary of the Sub-basin as compared to the previous groundwater head determination scenario (Scenario 1).

In figure $7 \mathrm{~b}$ (simulation 2, scenario 5); the groundwater head due to climate change with human pressure was varied from 
$5.66 \mathrm{~m}$ in the Southern boundary to $38.87 \mathrm{~m}$ in the northwestern of the Sub-basin. The decreased pumping rate was replying to the groundwater head at the end of (2021) has increased by 0.38 $\mathrm{m}$ in the valley floor of the Sub-basin due to the drainage effect of the flow and increased by $2.23 \mathrm{~m}$ in the northwestern boundary of the Sub-basin as compared to the previous groundwater head determination scenario (Scenario 1).

\subsubsection{Drawdown}

The groundwater had abstracted for different purposes; the drawdown level was changing from normal conditions. The predicted drawdown level in those scenario analyses has been little variation with time.

In the above figure (Figure 8) simulation 1 scenario 1; the
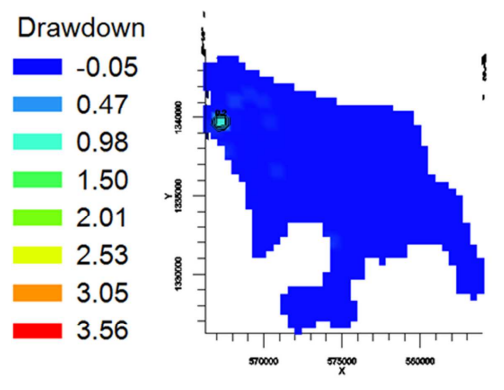

a predicted drawdown level after two years has been a maximum depth of $6.2 \mathrm{~m}$ around the pumped wells.

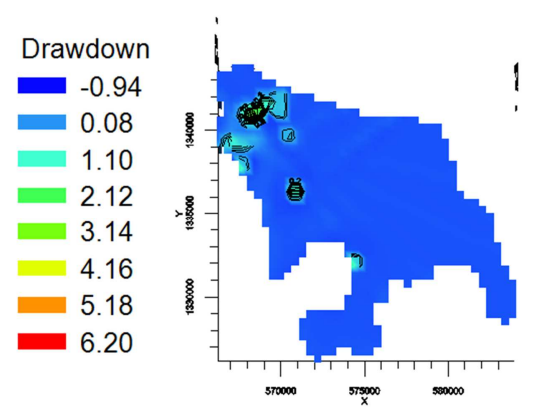

Figure 8. The predicted drawdown level of using constant pumping wells.
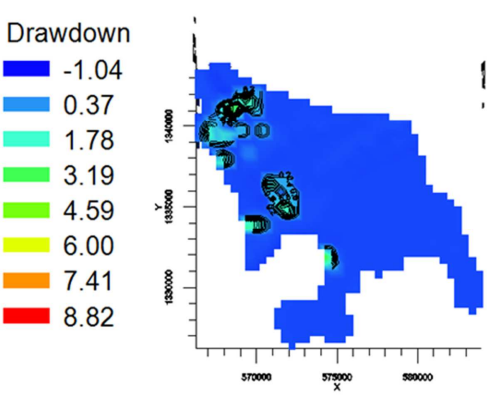

Figure 9. The predicted drawdown level of variation of pumping wells.

In the above figure (Figure 9 a) in the first simulation scenario 2, the predicted drawdown level has been modeled from a maximum depth of $3.56 \mathrm{~m}$ in the Northwestern boundary due to the effect of increased pumping wells. Figure $9 \mathrm{~b}$ (simulation 1, scenario 3); the predicted drawdown level had modeled from a maximum depth of 8.82 $\mathrm{m}$ in the northwestern boundary.
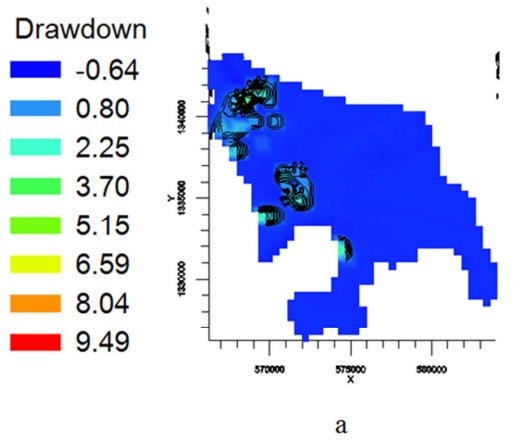

The decreased and increased pumping rate with constant recharge rate was replying to the drawdown level at the end of (2021) decreased by $2.64 \mathrm{~m}$ and increased by $2.6 \mathrm{~m}$ respectively in the Northwestern boundary of the Sub-basin as compared as the previous drawdown determination scenario (Scenario 1).

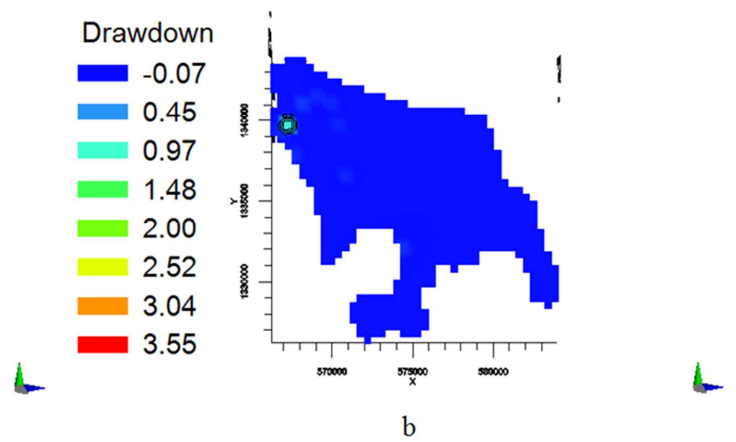

Figure 10. The predicted drawdown level of due to climate change.

In the above figure (Figure 10 a) in the second simulation scenario 4 , the predicted drawdown level had a maximum depth of $9.49 \mathrm{~m}$. In Scenario 5 (figure $10 \mathrm{~b}$ ), the drawdown level produced to a maximum depth of $3.55 \mathrm{~m}$ due to the effect of changing recharge rates. The increased and decreased pumping rate with variable recharge rate had shown to the drawdown level at the end of 2021 becomes increased by $3.29 \mathrm{~m}$ and lower by $2.65 \mathrm{~m}$ respectively in the Northwestern boundary of the Subbasin as compared as the previous drawdown determination scenario (Scenario 1).

\section{Summary and Conclusions}

\subsection{Summary}

This study was intending to obtain a better understanding of the groundwater flow systems in Hormat-Golina Subbasin by applying a visual mod flow flex numerical groundwater flow model. 
The simulated groundwater head and its respected drawdown model results have highly varied before and after irrigation season. The initial head values before irrigation season had recorded during January 2019. The head result obtained varied to a maximum of $0.8 \mathrm{~m}$ as compared to the measured depth of the initial heads from after irrigation season. The field observation with the model had used to realize the characteristics of the groundwater system under transient state conditions for groundwater head determination despite the uncertainties.

The groundwater elevation has varied within a given three month's irrigation period with a $39.055 \mathrm{~mm}$ per year recharge rate. The predicted simulation of the model had different pumping scenarios response to the groundwater head from using $23.28 \times 103 \mathrm{~m} 3 / \mathrm{d}$ in 17 supply wells to $43.68 * 103 \mathrm{~m} 3 / \mathrm{d}$ in 34 supply wells.

The decreased pumping rate with increased recharge rate has likely to reply to the groundwater head at the end of 2021 increase by $2.23 \mathrm{~m}$ in the northwestern boundary of the Subbasin. The increased pumping rate with decreased recharge rate has likely to respond to the groundwater head at the end of 2021was decreased by $2.81 \mathrm{~m}$ in the northwestern boundary of the Sub-basin.

\subsection{Conclusions}

The following conclusions had drawn from the results obtained from this study.

The groundwater head before irrigation season had found to be higher than the groundwater head after irrigation season since pumping rates can have to control its level. Besides, the model simulated head contour map has shown that the general hydraulic gradient in the Sub-basin pursues the hydraulic gradient was locating from the Northern boundary towards to Southern direction. Reduced pumping rate with increased recharge rate scenario was an acceptable range in terms of groundwater management, and future sustainability has been suffering from an over exploration of the groundwater from the unconfined aquifer. The hydraulic conductivity value of the model was a highly sensible parameter.

\section{References}

[1] Anderson, M and Wossener, W. W. 1992. Applied groundwater modeling simulation of flow and advective transport, Florida.

[2] Brouyere, S., Carabin, G. and Dassargues, A. 2004. Climate change impacts on groundwater resources: modeled deficits in a chalky aquifer, Geer basin, Belgium, Hydrogeology Journal, Volume. 12, P. 123-134.

[3] Chiang, W. H. 2005. 3D groundwater modeling with PMWIN: A Simulation system for modeling groundwater flow and transport processes. Second edition, ISBN-13978-3-54027590-9, Springer Berlin Heidelberg New York.

[4] Craig, C., Rick, E., Susan, H., Rafik, H., Gabrielle, P. and Carolina, P. 2010. Water and Climate Change: Impacts on groundwater resources and adaptation options. Water Working Notes are published by the Water Sector Board of the Sustainable Development Network of the World Bank Group. Note number, 25.

[5] Crosbie, R., McCallum, J., Walker, G. and Chiew, F. 2010. Modeling in climate change impacts on groundwater recharge in the Murray-Darling Basin, Australia. Hydrogeology Journal, Vol 18 No7, P. 1639-1656.

[6] Delleur, J. 1999. The handbook of Groundwater Engineering. ISBN 0-8493-2698-2 (CRC Press), U.S.A and Canada ISBN 3-540-64745-7 (Springer-Verlag), Germany.

[7] Herrera, P. M. and Hiscock, K. 2008. The effects of climate change on potential groundwater recharge in Great Britain.

[8] Hogeboom, H. J. Pieter, R., Maarten, S. and Martijn, J. 2013. Modeling the Influence of Groundwater Abstractions on the Water Level of Lake Naivasha, Kenya Under Data-Scarce Conditions, University of Twente, Netherland. Department of Water Engineering \& Management (WEM). Volume 29 issue 12, P. 4447-4463.

[9] Semu Moges. 2012. Agricultural Use of Groundwater in Ethiopia: Assessment of Potential and Analysis of Economics, Policies, Constraints and Opportunities. Addis Ababa University, Ethiopia.

[10] Todd, D. K. 2005. Groundwater Hydrology. Third edition ISBN 0-471-05937-4 (cloth) and ISBN 0-471-45254-8 (WIE). 